\title{
Rubinstein-Taybi Syndrome Type 1
}

National Cancer Institute

\section{Source}

National Cancer Institute. Rubinstein-Taybi Syndrome Type 1. NCI Thesaurus. Code C153290.

The most common form of Rubinstein-T aybi syndrome, caused by a mutation in the CREB binding protein (CREBBP) gene. 